\title{
Transcription Factor SOX-8
}

National Cancer Institute

\section{Source}

National Cancer Institute. Transcription Factor SOX-8. NCI Thesaurus. Code C97205.

Transcription factor SOX-8 (446 aa, $\sim 47 \mathrm{kDa}$ ) is encoded by the human SOX8 gene. This protein is involved in the activation of transcription. 